\title{
Packed bed column dynamic study for boron removal from geothermal brine by a chelating fiber and breakthrough curve analysis by using mathematical models
}

\author{
Yaşar K. Recepoğlu ${ }^{\mathrm{a}, \mathrm{d}}$, Nalan Kabay ${ }^{\mathrm{a}, *}$, Idil Yılmaz Ipek ${ }^{\mathrm{a}}$, Müşerref Arda ${ }^{\mathrm{b}}$, Mithat Yüksel $^{\mathrm{a}}$, \\ Kazuharu Yoshizuka ${ }^{c}$, Syouhei Nishihama ${ }^{\mathrm{c}}$ \\ ${ }^{a}$ Ege University, Faculty of Engineering, Chemical Engineering Department, 35100 Izmir, Turkey \\ ${ }^{\mathrm{b}}$ Ege University, Faculty of Science, Chemistry Department, 35100 Izmir, Turkey \\ ${ }^{c}$ The University of Kitakyushu, Faculty of Environmental Engineering, Department of Chemical Engineering, Hibikino 1-1, Kitakyushu 808-0135, Japan \\ d Izmir Institute of Technology, Faculty of Engineering, Department of Chemical Engineering, 35430 Izmir, Turkey
}

\section{G R A P H I C A L A B S T R A C T}

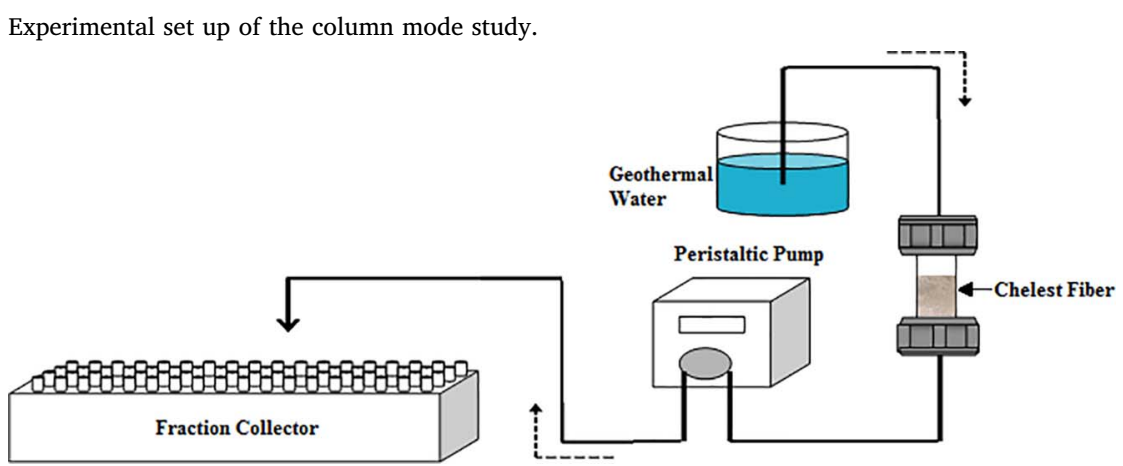

\section{A R T I C L E I N F O}

\section{Keywords:}

Boron

Chelest fiber

Geothermal brine

Packed bed column

Modified dose response (MDR) model

Thomas model

Yoon-Nelson model

\begin{abstract}
A B S T R A C T
In this study, the performance of $N$-methyl-D-glucamine (NMDG) type functional group attached a novel boron selective chelating fiber adsorbent, Chelest Fiber GRY-HW, was investigated for boron removal from geothermal brine containing 10-11 mg B/L through a packed bed column. The effect of feed flow rate (Space Velocity, SV) on breakthrough capacity of Chelest Fiber GRY-HW was studied using various SV values $\left(15,20 \mathrm{and}_{30} \mathrm{~h}^{-1}\right.$ ). The effect of SV on breakthrough capacity was particularly apparent when SV was decreased from 30 to $15 \mathrm{~h}^{-1}$. Yoon-Nelson, Thomas and Modified Dose Response (MDR) models were applied to the experimental data to estimate the breakthrough curves and model parameters such as rate constants and breakthrough times. The obtained results showed that the breakthrough curves were better described by Modified Dose Response (MDR) model than those described by Yoon-Nelson and Thomas models in each case. Also, the model estimations for adsorption capacity obtained by MDR model agreed well with the experimental results.
\end{abstract}

\section{Introduction}

Although boron toxicity issue was first noticed by the farmers using post-treated product water for irrigation coming from a seawater reverse osmosis (SWRO) plant established in Eilat, Israel, in 1997, deboronation of aqueous mediums containing high boron concentration is

\footnotetext{
* Corresponding author.

E-mail address: nalan.kabay@ege.edu.tr (N. Kabay).
} 
still a hot topic due to the harmful effects of boron to plants which have been clearly stated in the literature [1-6]. Consequently, strict standard values on the concentration of boron, such as $2.4 \mathrm{mg} / \mathrm{L}$ for drinking water and $1 \mathrm{mg} / \mathrm{L}$ for irrigation water, have been enforced by the environmental authorities [7]. There is not any unique method exists for boron removal from water. One or more methods can be applied based on the boron concentration in the medium. Adsorption onto fly ash [8], chemical precipitation [9], nanofiltration, reverse osmosis [10-16], electrodialysis [17], ion exchange-microfiltration [1,18,19], as well as ion exchange-ultrafiltration hybrid processes [2,20-22], electrodeionization [23] are some of the separation methods for boron.

The most extensively used technology for the removal of boron from aqueous solutions is the ion exchange using boron selective chelating resin [3,6,24-34]. The earlier studies on boron removal began with $\mathrm{N}$ glucamine-type commercial resins, Diaion CRB 02 and Purolite S 108, using geothermal brine where $\mathrm{Na}^{+}, \mathrm{K}^{+}, \mathrm{Cl}^{-}, \mathrm{SO}_{4}{ }^{2-}, \mathrm{HCO}_{3}{ }^{-}, \mathrm{CO}_{3}{ }^{2-}$ are major ionic components. Since geothermal brine has also certain salts, the effect of salinity on boron removal by those chelating ion-exchange resins in the presence of some salts such as sodium chloride and calcium chloride was also investigated. The results showed some decrease in the removal of boron from geothermal water in the presence of $\mathrm{Ca}, \mathrm{Na}$, and $\mathrm{Cl}$ ions. However, it was reported that the removal of boron was not influenced by an increase in the concentrations of these ions [24,25].

Nowadays, synthesis and advancement of new selective chelating resins and fibers with high selectivity, large capacity and fast sorption rate have received great attention notably for separation of boron from water [31-33,35,36]. However, adsorbents based on a natural polymer could be more preferable from the viewpoints of being eco-friendly materials. The branched-saccharide-chitosan resins to obtain a novel adsorbent derived from a natural polymer has been evolved and tested for boron removal [37]. Commercially available Chelest Fiber GRY-HW is one of a cellulose-based natural polymer which contains $N$-methyl-Dglucamine group. It has also been developed recently that this fibrous adsorbent found to possess a faster adsorption kinetic for boron than that of boron selective chelating ion exchange resins [35]. So far, we have compared the performance of Chelest Fiber with ion exchange resins, Diaion CRB 02 and CRB 05, by batch and column mode tests for removal of boron from geothermal brine [38]. Moreover, Ting et al. [39] evaluated the adsorption of boron from model solutions on new radiation grafted fibrous adsorbent containing $N$-methyl-D-glucamine [39]. Recently, a novel type poly (amic acid) (PAA) electrospun nanofiber membranes grafted with hyperbranched polyols were synthesized and used for the removal of boron from aqueous solutions [40].

Even though conducting those materials by batch adsorption is more appropriate for treatment of small volumes, it becomes an inconvenient method if there is a large volume to be treated due to overestimation of sorption capacities. Thus, utilization of them in a fixed bed column is more favorable in order to obtain more realistic laboratory results which has a great resemblance to the flow conditions in full scale constructed packed bed columns. In addition, a packed bed column dynamic study is important to anticipate the column breakthrough, which determines the functional life span of the column bed [41]. In this context, some models such as Yoon-Nelson model, Thomas model [41-44] and Modified Dose Response (MDR) model [41] were established to describe the dynamic behavior of adsorptive materials when packed into a column.

In this study, a novel chelating cellulose based fiber was used as adsorbent for the column-mode removal of boron from geothermal brine. The aim of the present investigation was to describe the packed bed column dynamic behavior of Chelest Fiber GRY-HW for sorption of boron from geothermal brine having certain salinity by applying three different mathematical models as a function of feed flow rate.
Table 1

Properties of Chelest Fiber GRY-HW.

\begin{tabular}{ll}
\hline Support material & Cellulose based fiber \\
\hline True specific gravity & 1.5 \\
Water content (\%) & $<45$ \\
Length of fiber (mm, approx.) & 0.5 \\
Diameter of fiber ( $\mu$ m, approx.) & 100 \\
Chelate amount (mmol/g) & 1.3 \\
Functional group & $\mathrm{CH}_{3}$ \\
& $\mathrm{CH}-\mathrm{N}-\mathrm{CH}_{2}-(\mathrm{CH}(\mathrm{OH}))_{4}-\mathrm{CH}_{2} \mathrm{OH}$ \\
& $(N-$ methyl-D-glucamine $)$ \\
\hline
\end{tabular}

\section{Experimental}

\subsection{Materials}

Boron selective chelating ion exchange fiber, Chelest Fiber GRYHW, was provided from Chelest Co., Japan. The properties of fiber adsorbent containing $\mathrm{N}$-methyl-D-glucamine type functional group based on catalogue values are given in Table 1 .

Geothermal brine obtained from Izmir Geothermal Co., Turkey was used in the experimental studies. The characteristics of geothermal brine sampled at different time periods were listed in Table 2 .

\subsection{Methods}

A column of $0.7 \mathrm{~cm}$ diameter and $10 \mathrm{~cm}$ height packed with Chelest Fiber GRY-HW (wet wolume $0.5 \mathrm{~mL}$ ) was used in chromatographic separation of boron from geothermal brine. The schematic view of experimental set up was given in Fig. 1. The geothermal brine was fed downward through the column at different space velocities (SV 15, 20 and $30 \mathrm{~h}^{-1}$ ). A $3 \mathrm{~mL}$ (6 BV) of fractions were collected by the help of a peristaltic pump (ISMATEC model) and a fraction collector (both Advantec, CHF100SA and TELEDYNE ISCO). Elution was performed with a $5 \%$ of $\mathrm{H}_{2} \mathrm{SO}_{4}$ solution at SV $10 \mathrm{~h}^{-1}$ by collecting $2 \mathrm{~mL}$ (4 BV) of fractions. Boron concentration of samples was determined by Curcumine method at $543 \mathrm{~nm}$ using Jasco V-530 model uv-vis spectrophotometer.

\section{Theory}

The bed volume ( $B V, \mathrm{~mL}$ geothermal brine/mL fiber) was calculated from Eq. (1) [45]:

$B V=\frac{Q t}{V}$

where $Q$ is feed solution flow rate ( $\mathrm{mL} / \mathrm{min}), t$ is operating time (min) and $V$ is adsorbent wet volume $(\mathrm{mL})$.

In addition, space velocity $\left(S V, \min ^{-1}\right.$ or $\left.\mathrm{h}^{-1}\right)$ is the ratio of feed solution flow rate and adsorbent wet volume as in Eq. (2).

$S V=\frac{Q}{V}$

\subsection{Yoon-Nelson model}

A relatively straightforward model focused on the adsorption of gases or vapors in activated carbon was developed by Yoon-Nelson which depends on the rate of decrease in the possibility of adsorption for each adsorbate molecule being proportional to the possibility of sorbate sorption and the probability of sorbate breakthrough on adsorbent [44]. Yoon-Nelson equation is given as follows in Eq. (3):

$\frac{C}{C_{o}}=\frac{\exp \left(K_{Y N} t-\tau K_{Y N}\right)}{1+\exp \left(K_{Y N} t-\tau K_{Y N}\right)}$ 
Table 2

Characteristics of the geothermal brine samples.

\begin{tabular}{|c|c|c|c|c|c|}
\hline Parameters & Value & Cations & Concentration (mg/L) & Anions & Concentration $(\mathrm{mg} / \mathrm{L})$ \\
\hline $\mathrm{pH}^{\mathrm{a}}$ & $7.91 \pm 0.66$ & $\mathrm{Li}^{+\mathrm{c}}$ & $1.18 \pm 0.01$ & $\mathrm{HCO}_{3}{ }^{-\mathrm{b}}$ & $583.15 \pm 43.49$ \\
\hline $\mathrm{EC}^{\mathrm{a}}(\mathrm{mS} / \mathrm{cm})$ & $1.75 \pm 0.16$ & $\mathrm{Na}^{+\mathrm{c}}$ & $569.3 \pm 259.79$ & $\mathrm{~F}^{-\mathrm{c}}$ & $8.26 \pm 2.74$ \\
\hline $\mathrm{TDS}^{\mathrm{a}}(\mathrm{g} / \mathrm{L})$ & $0.88 \pm 0.09$ & $\mathrm{~K}^{+\mathrm{c}}$ & $36.2 \pm 10.61$ & $\mathrm{Cl}^{-\mathrm{c}}$ & $311 \pm 31.11$ \\
\hline Salinity $^{\mathrm{a}}(\% 0)$ & $0.89 \pm 0.09$ & $\mathrm{NH}_{4}{ }^{+\mathrm{c}}$ & $22.06 \pm 26.80$ & $\mathrm{NO}_{3}{ }^{-\mathrm{c}}$ & $0.735 \pm 1.04$ \\
\hline \multirow[t]{2}{*}{$\mathrm{B}(\mathrm{mg} / \mathrm{L})^{\mathrm{d}}$} & $10.22 \pm 0.03$ & $\mathrm{Ca}^{2+\mathrm{c}}$ & $16.39 \pm 11.90$ & $\mathrm{SO}_{4}{ }^{2-\mathrm{c}}$ & $191.15 \pm 60.60$ \\
\hline & & $\mathrm{Mg}^{2+c}$ & $24.08 \pm 9.02$ & & \\
\hline
\end{tabular}

a Hachlange HQ14D model multimeter.

b Titrimetric method.

c Shimadzu model ion chromatography (Prominence HIC-SP model).

${ }^{\mathrm{d}}$ Spectrophotometric method (Shimadzu UV-1800 uv-vis spectrophotometer).

where $K_{Y N}$ is the rate constant $\left(\mathrm{min}^{-1}\right)$; and $\tau$ is, the time required for $50 \%$ sorbate breakthrough $(\mathrm{min})$ when concentration at any time $(C$, $\mathrm{mg} / \mathrm{L})$ is one-half of initial concentration $\left(C_{o}, \mathrm{mg} / \mathrm{L}\right)$. In order to determine $K_{Y N}$ and $\tau$, linearized form of Yoon-Nelson equation described in Eq. (4) can be plotted as $\ln \left(C /\left(C_{o}-C\right)\right)$ vs. $t$ in which slope and intercept are used, respectively.

$\ln \frac{C}{C_{o}-C}=K_{Y N} t-\tau K_{Y N}$

After all, adsorption capacity $\left(\mathrm{q}_{\mathrm{o}}, \mathrm{mg} / \mathrm{g}\right)$ can be evaluated by using Eq. (5):

$q_{o}=\frac{1}{2} \frac{\left(C_{o} Q 2 \tau\right)}{m}=\frac{\left(C_{o} Q \tau\right)}{m}$

where $m$ is the adsorbent amount ( $g$ ) additionally. According to the model, the amount of boron adsorbed by the fiber is one half of initial boron concentration passed through the packed-bed column within the $2 \tau$ period.

\subsection{Thomas model}

The adsorption rate constant and the maximum solid phase concentration of solute on the adsorbent for an adsorption column can be estimated by using Thomas model. The model assumes Langmuir kinetics of adsorption-desorption and no axial dispersion so that the driving force for adsorption obeys reversible second-order reaction kinetics. The main constraint of this model is that sorption is controlled by the mass transfer at the interface but it is not limited by the chemical reaction [44]. Thomas model can be expressed as in the following Eq. (6):

$\frac{C}{C_{0}}=\frac{1}{1+\exp \left(K_{T}\left(q_{o} m-C_{0} \vartheta\right) / Q\right)}$

where $K_{T}$ is the Thomas rate constant $(\mathrm{mL} /(\mathrm{min} \mathrm{mg}))$ and $\vartheta$ is the total solution volume passed through the column at any time as well as other parameters defined before. The linearized form of the Thomas model can be written as in Eq. (7) where values of $K_{T}$ and adsorption capacity, $q_{o}$ can be found from the slope and the intercept of the plot between ln $\left(\left(C_{o} / C\right)-1\right)$ vs. time $(\vartheta / Q)$, respectively.

$\ln \left(\frac{C_{0}}{C}-1\right)=\frac{K_{T} q_{o} m}{Q}-\frac{K_{T} C_{0}}{Q} \vartheta$

\subsection{Modified dose response model (MDR)}

Another simplified numerical model used to evaluate dynamic behavior of a packed bed column adsorption data is the Modified Dose Response model $[41,42]$. This model mainly lowers the error resulting from the use of the Thomas model, particularly at lower or higher time periods of the breakthrough curve. The mathematical model is written in Eq. (8):

$\frac{C}{C_{0}}=1-\frac{1}{1+\left(\frac{\vartheta}{b}\right)^{a}}$

where $a$ and $b$ are Modified Dose Response model constants. The parameter $b$ denotes the throughput volume that produces a halfmaximum response and $a$ decides the slope of the regression function [42]. From the value of $b$, the value of the maximum solid phase concentration of the solute $\left(q_{m}\right)$ can be anticipated by using Eq. (9):

$q_{m}=\frac{b C_{o}}{m}$

Nonlinear regression method was followed to fit the experimentally obtained data into the Modified Dose Response model as given in Eq. (8).

In order to find the best fit model, error analysis was performed by considering the sum of the squares of the differences between the experimental data and the theoretical data (by calculating from models). Sum of the Squares of Error (SSE) [41] can be obtained as in the following Eq. (10):

$S S E=\frac{\sum\left(\left(\frac{C}{C_{o}}\right)_{\text {theo }}-\left(\frac{C}{C_{0}}\right)_{\exp }\right)^{2}}{N}$

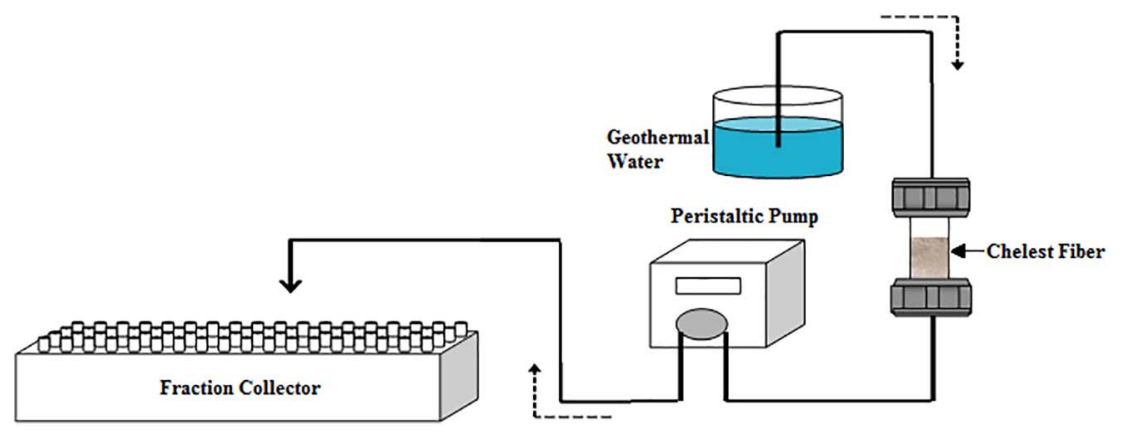

Fig. 1. Experimental set up of the column mode study. 


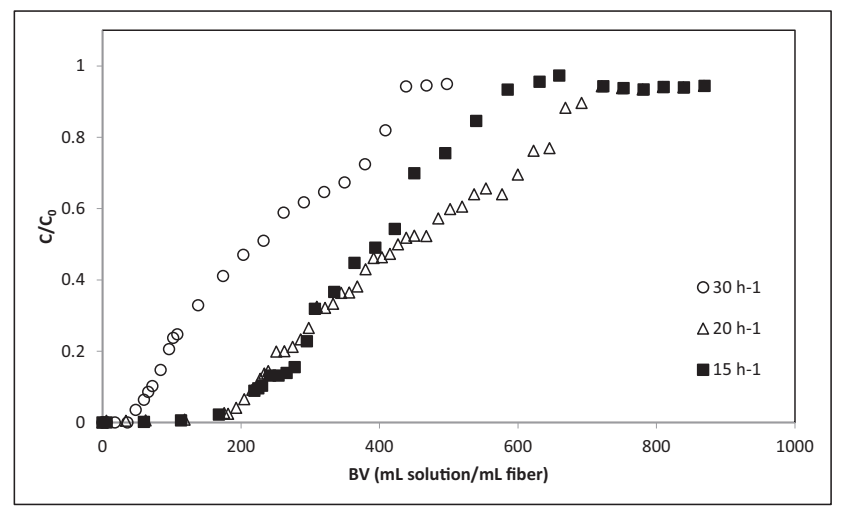

Fig. 2. Breaktrough profiles of boron by Chelest Fiber at different SV.

where $\left(C / C_{\mathrm{o}}\right)_{\text {theo }}$ is the ratio of effluent and initial boron concentration obtained from the model calculation, $\left(C / C_{0}\right)_{\exp }$ is the ratio of effluent and influent boron concentration obtained from the experiment and $N$ is the total number of experimental point.

\section{Results and discussion}

The geothermal brine has an average salinity with predominance of chloride, sodium, sulfate, calcium and bicarbonate ions. However, due to its high boron content, this geothermal water even with lower mineralization cannot be utilized as alternative resource for the agricultural and domestic sectors without further treatment.

As a continuous method for boron removal from geothermal brine having ca. $10.5 \mathrm{mg} \mathrm{B/L}$, column studies were run with Chelest Fiber GRY-HW at different space velocities (SV 15, 20 and $30 \mathrm{~h}^{-1}$ ). Flow rate is an important parameter for determining the efficiency of adsorbents in continuous treatment process of effluents. The effect of feed flow rate on breakthrough point was particularly apparent when SV decreased from 30 to $15 \mathrm{~h}^{-1}$ (Fig. 2). This could be referred to the increase in speed of adsorption zone at a higher flow rate, which resulted in a decrease in the time required to reach the specific breakthrough concentration [44]. Table 3 compares the capacity and elution efficiency values obtained using Chelest Fiber GRY-HW at different flow rates. According to the results, breakthrough and total capacities of the fiber adsorbent were found to be 7.25 and $13.47 \mathrm{mg} / \mathrm{g}$-fiber, respectively at SV $15 \mathrm{~h}^{-1}$. Comparison of elution curves were shown in Fig. 3. Due to less contact time for adsorption and diffusion limitations of sorbate on the adsorbent in column at a higher flow rates, less boron was uptaken from geothermal brine by Chelest Fiber. In our previous study conducted using a batch mode of operation, the total adsorption capacity of

Table 3

Column sorption-elution data for boron uptake by Chelest Fiber at different SV.

\begin{tabular}{|c|c|c|c|}
\hline & SV $30 \mathrm{~h}^{-1}$ & SV $20 \mathrm{~h}^{-1}$ & SV $15 h^{-1}$ \\
\hline $\begin{array}{l}\text { Breakthrough capacity } \\
\text { (mg B/mL fiber) }\end{array}$ & 0.68 & 2.16 & 2.59 \\
\hline $\begin{array}{l}\text { Breakthrough capacity } \\
\text { (mg B/g fiber) }\end{array}$ & 1.90 & 6.05 & 7.25 \\
\hline $\begin{array}{l}\text { BV for breakthrough point } \\
\text { (mL solution/mL fiber) }\end{array}$ & 66 & 216 & 225 \\
\hline $\begin{array}{l}\text { Total ion exchange capacity } \\
\text { (mg B/mL fiber) }\end{array}$ & 2.50 & 4.66 & 4.81 \\
\hline $\begin{array}{l}\text { Total ion exchange capacity } \\
\text { (mg B/g fiber) }\end{array}$ & 7.00 & 13.05 & 13.47 \\
\hline $\begin{array}{l}\text { BV for total capacity } \\
\text { (mL solution/mL fiber) }\end{array}$ & 498 & 869 & 899 \\
\hline $\begin{array}{l}\text { Degree of column utilization } \\
\quad(\%)\end{array}$ & 27 & 46 & 54 \\
\hline $\begin{array}{l}\text { Elution efficiency } \\
\quad(\%)\end{array}$ & 88 & 89 & 89 \\
\hline
\end{tabular}

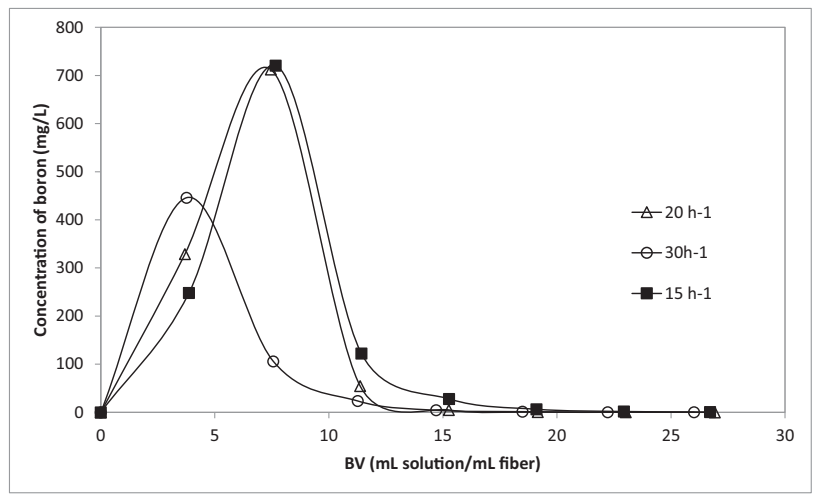

Fig. 3. Elution profiles of boron.

this fiber adsorbent were found to be $18.52 \mathrm{mg} / \mathrm{g}$-fiber due to testing it with spiked geothermal brine having ca. $100 \mathrm{mg} \mathrm{B} / \mathrm{L}$ as the highest initial boron concentration [38]. So, the initial concentration has an important effect on adsorption capacity. Elsewhere, the elution efficiencies were almost around $90 \%$ for all sorption tests run at different flow rates.

\subsection{Analysis by Yoon-Nelson model}

Yoon-Nelson model was used to predict column adsorption test results. Yoon-Nelson model parameters such as $K_{Y N}$ and $\tau$ were determined for column studies performed at different flow rates. As seen in Table 4, the rate constant $K_{Y N}$ increased with increasing flow rate whereas $\tau$ decreased due to the decrease of the contact time. This result explained that the contact time was not enough for boron to diffuse into the pores so that available functional group sites could not be captured by more boron inside or around the adsorbent. Moreover, with the increase of flow rate from SV $15 \mathrm{~h}^{-1}$ to $30 \mathrm{~h}^{-1}$, the total capacity of Chelest Fiber adsorbent decreased a bit from 12.75 to $12.20 \mathrm{mg} \mathrm{B} / \mathrm{g}$ fiber. This result also indicated that the equilibrium capacity was quickly reached to its maximum value at higher flow rates due to the diffusion limitations of adsorbate on the adsorbent [44]. The calculated $\tau$ and adsorption capacity values were found to be almost similar to the experimental results. Apparently, the estimated breakthrough curves are consistent with the experimental ones as shown in Fig. 4 although similarity increased with decreasing flow rates. Similar types of results were reported by Yılmaz-İpek et al. [43] and Bilgin-Şimşek et al. [44].

\subsection{Analysis by Thomas model}

The Thomas model was applied between the saturation time and the breakthrough time in the column. Although Thomas rate constant, $K_{T}$, tends to increase and $q_{o, \text { exp }}$ decreased when the SV increased as expected, the experimental results were not satisfactorily obeyed as well as Yoon-Nelson model as seen in Fig. 5. The highest SSE values ranging from 0.061 to 0.128 belong to Thomas model were tabulated in Table 5 .

Table 4

Model parameters and adsorption capacities obtained by Yoon-Nelson model to estimate breakthrough curves using Chelest Fiber GRY-HW.

\begin{tabular}{llll}
\hline & $\begin{array}{l}\mathrm{SV} 15 \mathrm{~h}^{-1} \\
(0.125 \mathrm{~mL} / \mathrm{min})\end{array}$ & $\begin{array}{l}\mathrm{SV} 20 \mathrm{~h}^{-1} \\
(0.165 \mathrm{~mL} / \mathrm{min})\end{array}$ & $\begin{array}{l}\mathrm{SV} 30 \mathrm{~h}^{-1} \\
(0.250 \mathrm{~mL} / \mathrm{min})\end{array}$ \\
\hline $\mathrm{K}_{\mathrm{YN}}\left(\mathrm{min}^{-1}\right)$ & 0.0023 & 0.0029 & 0.0031 \\
$\tau_{\text {experimental }}(\mathrm{min})$ & 1645.83 & 1368.17 & 440.23 \\
$\tau_{\text {calculated }}(\mathrm{min})$ & 1662.55 & 1294.11 & 461.05 \\
$\mathrm{q}_{\text {o, exper }}(\mathrm{mg} / \mathrm{g})$ & 12.75 & 12.20 & 6.34 \\
$\mathrm{q}_{\text {o, theo }}(\mathrm{mg} / \mathrm{g})$ & 12.32 & 12.06 & 6.65 \\
$\mathrm{SSE}$ & 0.001 & 0.002 & 0.010 \\
\hline
\end{tabular}

$\mathrm{q}_{\mathrm{o}}$, exp: $\mathrm{q}_{\mathrm{o}}$ obtained experimentally; $\mathrm{q}_{\mathrm{o}}$, theo: $\mathrm{q}_{\mathrm{o}}$ calculated theoretically. 


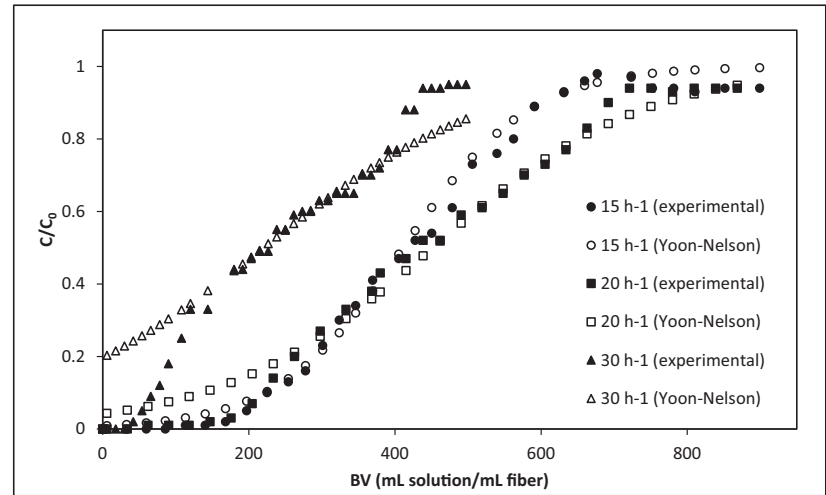

Fig. 4. Comparison of breakthrough curves obtained experimentally and theoretically by Yoon-Nelson model.

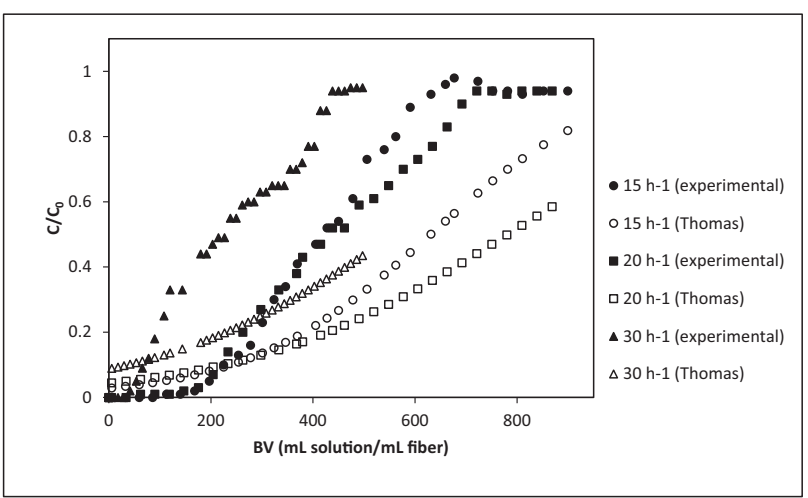

Fig. 5. Comparison of breakthrough curves obtained experimentally and theoretically by Thomas model.

Table 5

Model parameters and adsorption capacities obtained by Thomas model to estimate breakthrough curves using Chelest Fiber GRY-HW

\begin{tabular}{llll}
\hline & $\begin{array}{l}\text { SV } 15 \mathrm{~h}^{-1} \\
(0.125 \mathrm{~mL} / \mathrm{min})\end{array}$ & $\begin{array}{l}\mathrm{SV} 20 \mathrm{~h}^{-1} \\
(0.165 \mathrm{~mL} / \mathrm{min})\end{array}$ & $\begin{array}{l}\mathrm{SV} 30 \mathrm{~h}^{-1} \\
(0.250 \mathrm{~mL} / \mathrm{min})\end{array}$ \\
\hline $\mathrm{K}_{\mathrm{T}}(\mathrm{mL} /$ & 0.131 & 0.128 & 0.202 \\
$\mathrm{~min} \mathrm{mg})$ & & & \\
$\mathrm{q}_{\mathrm{o}, \exp }(\mathrm{mg} / \mathrm{g})$ & 22.06 & 18.69 & 16.13 \\
$\mathrm{q}_{\mathrm{o}, \text { theor }}(\mathrm{mg} / \mathrm{g})$ & 23.14 & 19.23 & 16.01 \\
$\mathrm{SSE}$ & 0.061 & 0.092 & 0.128 \\
\hline
\end{tabular}

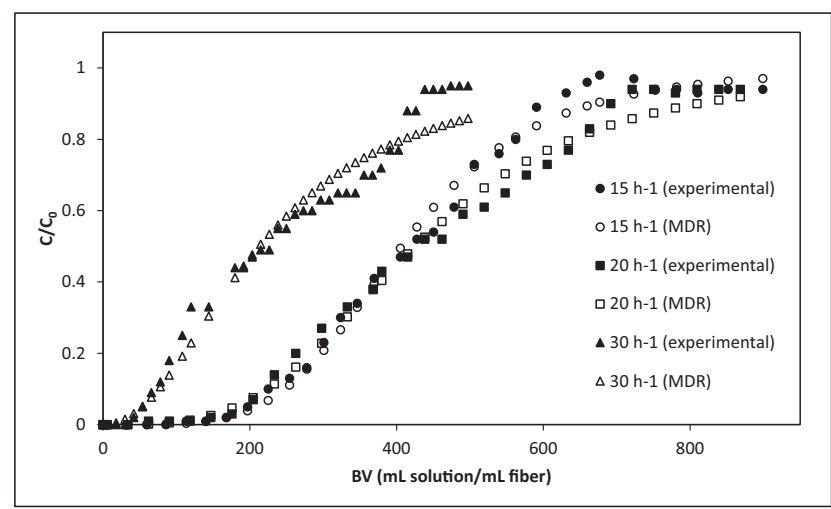

Fig. 6. Comparison of breakthrough curves obtained experimentally and theoretically by MDR model.
Table 6

Model parameters and adsorption capacities obtained by MDR model to estimate breakthrough curves using Chelest Fiber GRY-HW.

\begin{tabular}{llll}
\hline & $\begin{array}{l}\text { SV } 15 \mathrm{~h}^{-1} \\
(0.125 \mathrm{~mL} / \mathrm{min})\end{array}$ & $\begin{array}{l}\mathrm{SV} 20 \mathrm{~h}^{-1} \\
(0.165 \mathrm{~mL} / \mathrm{min})\end{array}$ & $\begin{array}{l}\mathrm{SV} 30 \mathrm{~h}^{-1} \\
(0.250 \mathrm{~mL} / \mathrm{min})\end{array}$ \\
\hline $\mathrm{a}$ & 4.420 & 3.416 & 2.12 \\
$\mathrm{~b}$ & 203.57 & 212.74 & 106.33 \\
$\mathrm{q}(\mathrm{mg} / \mathrm{g})$ & 12.07 & 12.02 & 6.13 \\
$\mathrm{SSE}$ & 0.001 & 0.001 & 0.003 \\
\hline
\end{tabular}

\subsection{Analysis by modified dose response (MDR) model}

Fig. 6 shows the breakthrough curves including both experimental and theoretically obtained one by Modified Dose Response (MDR) model for Chelest Fiber GRY-HW at different SV. The relevant constants, SSE values and parameters were presented in Table 6. As it is noticable from Fig. 6, along with remarkably low SSE (0.001-0.003) the estimated breakthrough curves of the MDR model demonstrated a superior agreement with the experimental data at all SV values. Additionally, the values of $b$ increased with the increase in SV or flow rate as well.

As interpreted the data listed in Tables 4-6, the values of SSE obtained from MDR model (0.001-0.003) were quite lower than that from Yoon-Nelson (0.001-0.010) and Thomas (0.061-0.128) models. Hence, it can be concluded that the MDR model can represent the adsorption behavior of Chelest Fiber GRY-HW for boron removal from geothermal brine by a chromatographic separation much better than Yoon-Nelson and Thomas models.

\section{Conclusions}

The experimental results revealed that a decrease in flow rate enhanced the longevity of column performance by increasing both breakthrough time and saturation time. When the experimental data obtained from dynamic studies were analyzed by using Yoon-Nelson, Thomas and Modified Dose Response models, the best fitting of the models to the experimental data followed the order of Modified Dose Response $>$ Yoon-Nelson $>$ Thomas.

Consequently, novel cellulose based fiber containing NMDG group (Chelest Fiber GRY-HW) was found to be a promising adsorbent for the removal of boron from geothermal brine due to its applicability for a continuous system.

\section{Acknowledgement}

This study was financially supported by TUBITAK-JSPS (Project number: 214M360). We are grateful to Izmir Geothermal Co. for sampling geothermal brine. We thank to Chelest Co., Japan for providing Chelest Fiber GRY-HW.

\section{References}

[1] N. Kabay, İ. İpek-Yılmaz, I. Soroko, M. Makowski, O. Kırmızısakal, S. Yağ, M. Bryjak, M. Yüksel, Removal of boron from Balcova geothermal water by ion exchange-microfiltration hybrid process, Desalination 241 (2009) 167-173.

[2] E. Güler, N. Kabay, M. Yüksel, N.Ö. Yiğit, M. Kitiş, M. Bryjak, Integrated solution for boron removal from seawater using RO process and sorption-membrane filtration hybrid method, J. Membr. Sci. 375 (2011) 249-257.

[3] J. Wolska, M. Bryjak, Methods for boron removal from aqueous solutions - a review, Desalination 310 (2013) 18-24.

[4] B. Wang, X. Guo, P. Bai, Removal technology of boron dissolved in aqueous solutions - a review, Colloids Surf. A Physicochem. Eng. Asp. 444 (2014) 338-344.

[5] B. Wang, H. Lin, X. Guo, P. Bai, Boron removal using chelating resins with pyrocatechol functional groups, Desalination 347 (2014) 138-143.

[6] E. Güler, C. Kaya, N. Kabay, M. Arda, Boron removal from seawater: state-of-the-art review, Desalination 356 (2015) 85-93.

[7] M. Korkmaz, C. Özmetin, B.A. Fil, Modelling of boron removal from solutions using Purolite S 108 in a batch reactor, Clean: Soil, Air, Water 44 (8) (2016) 949-958. 
[8] N. Öztürk, D. Kavak, Adsorption of boron from aqueous solutions using fly ash: batch and column studies, J. Hazard. Mater. 127 (1-3) (2005) 81-88.

[9] D. Kartikaningsih, Y.J. Shih, Y.H. Huang, Boron removal from boric acid wastewater by electrocoagulation using aluminum as sacrificial anode, Sustain. Environ. Res. 26 (2016) 150-155.

[10] H. Köseoğlu, N. Kabay, M. Yüksel, S. Sarp, Ö. Arar, M. Kitis, Boron removal from seawater using high rejection SWRO membranes- impact of $\mathrm{pH}$, feed concentration, pressure, and cross-flow velocity, Desalination 227 (2008) 253-263.

[11] S. Sarp, S. Lee, X.H. Ren, E. Lee, K. Chon, S.H. Choi, S. Kim, I.S. Kim, J. Cho, Boron removal from seawater using NF and RO membranes, and effects of boron on HEK 293 human embryonic kidney cell with respect to toxicities, Desalination 223 (1-3) (2008) 23-30.

[12] S.G. Öner, N. Kabay, E. Güler, M. Kitiş, M. Yüksel, A comparative study for the removal of boron and silica from geothermal water by cross-flow flat sheet reverse osmosis method, Desalination 283 (2011) 10-15.

[13] E. Güler, N. Kabay, M. Yüksel, E. Yavuz, Ü. Yüksel, A comparative study for boron removal from seawater by two types of polyamide thin film composite SWRO membranes, Desalination 273 (2011) 81-84.

[14] E. Yavuz, E. Güler, G. Sert, Ö. Arar, M. Yüksel, Ü. Yüksel, M. Kitiş, N. Kabay, Removal of boron from geothermal water by RO system-I-effect of membrane configuration and applied pressure, Desalination 310 (2013) 130-134.

[15] E. Yavuz, Ö. Arar, M. Yüksel, Ü. Yüksel, N. Kabay, Removal of boron from geothermal water by RO system-II-effect of pH, Desalination 310 (2013) 135-139.

[16] E. Yavuz, Ö. Arar, Ü. Yüksel, M. Yüksel, N. Kabay, Removal of boron from geothermal water by RO system-III-utilization of SWRO system, Desalination 310 (2013) 140-144.

[17] N. Kabay, O. Arar, F. Acar, A. Ghazal, U. Yuksel, M. Yuksel, Removal of boron from water by electrodialysis: effect of feed characteristics and interferingions, Desalination 223 (2008) 63-72.

[18] N. Kabay, İ. Yılmaz, M. Bryjak, M. Yüksel, Removal of boron from from aqueous solutions by ion exchange-membrane hybrid process, Desalination 198 (2006) 74-81.

[19] İ. Yllmaz, N. Kabay, M. Bryjak, M. Yüksel, J. Wolska, A. Koltuniewicz, A submergedion exchange hybrid process for boron removal, Desalination 198 (2006) 310-315.

[20] N. Kabay, P. Köseoğlu, E. Yavuz, Ü. Yüksel, M. Yüksel, An innovative integrated system for boron removal from geothermal water using RO process and ion exchange-ultrafiltration hybrid method, Desalination 316 (2013) 1-7.

[21] N. Kabay, P. Köseoğlu, D. Yapıcı, Ü. Yüksel, M. Yüksel, Coupling ion exchange with ultrafiltration for boron removal from geothermalwater-investigation of process parameters and recycle tests, Desalination 316 (2013) 17-22.

[22] S. Samatya, P. Köseoğlu, N. Kabay, A. Tuncel, M. Yüksel, Utilization of geothermal water as irrigation water after boron removal by monodisperse nanoporous polymers containing NMDG in sorption-ultrafiltration hybrid process, Desalination 364 (2015) 62-67.

[23] Ö. Arar, Ü. Yüksel, N. Kabay, M. Yüksel, Application of electrodeionization (EDI) for removal of boron and silica from reverse osmosis (RO) permeate of geothermal water, Desalination 310 (2013) 25-33.

[24] M. Badruk, N. Kabay, M. Demircioglu, H. Mordogan, U. Ipekoglu, Removal of boron from wastewater of geothermal power plant by selective ion exchange resins (I). Batch sorption-elution studies, Sep. Sci. Technol. 34 (13) (1999) 2553-2569.

[25] M. Badruk, N. Kabay, M. Demircioğlu, H. Mordogan, U. Ipekoglu, Removal of Boron from wastewater of geothermal power plant by selective ion exchange resins II. Column sorption-elution studies, Sep. Sci. Technol. 34 (15) (1999) 2981-2995.

[26] N. Kabay, I. Yilmaz, S. Yamac, S. Samatya, M. Yuksel, U. Yuksel, M. Arda, M. Sağlam, T. Iwanaga, K. Hirowatari, Removal and recovery of boron from geothermal wastewater by selective ion exchange resins. I. Laboratory tests, React. Funct. Polym. 60 (2004) 163-170.
[27] N. Kabay, I. Yilmaz, S. Yamac, M. Yuksel, U. Yuksel, N. Yildirim, O. Aydogdu, T. Iwanaga, K. Hirowatari, Removal and recovery of boron from geothermal wastewater by selective ion-exchange resins - II. Field tests, Desalination 167 (2004) $427-438$

[28] N. Kabay, E. Güler, M. Bryjak, Boron in seawater and its separation- a review, Desalination 261 (2010) 212-217.

[29] I. Yilmaz-Ipek, N. Kabay, M. Yuksel, O. Kirmizisakal, M. Bryjak, Removal of boron from Balçova-Izmir geothermal water by ion exchange process: batch and column processes, Chem. Eng. Commun. 196 (2009) 277-289.

[30] I. Yilmaz-Ipek, P. Koseoglu, U. Yuksel, N. Yasar, G. Yolseven, M. Yuksel, N. Kabay, Separation of boron from geothermal water using a boron selective macroporous weak base anion exchange resin, Sep. Sci. Technol. 45 (2010) 809-813.

[31] S. Samatya, N. Kabay, A. Tuncel, Monodisperse porous $N$-methyl-D-glucamine functionalized poly(vinylbenzyl chloride-co-divinylbenzene) beads as boron selective sorbent, J. Appl. Polym. Sci. 126 (4) (2012) 1475-1483.

[32] S. Samatya, A. Tuncel, N. Kabay, Boron removal from geothermal water by a novel monodisperse porous poly(GMA-co-EDM) resin containing $N$-methyl-D-Glucamine functional group, Solvent Extr. Ion Exch. 30 (2012) 341-349.

[33] P. Santander, B.L. Rivas, B.F. Urbano, I. Yilmaz-Ipek, G. Özkula, M. Arda, M. Yüksel, M. Bryjak, T. Kozlecki, N. Kabay, Removal of boron from geothermal water by a novel boron selective resin, Desalination 310 (2013) 102-108.

[34] M.M. Nasef, M. Nallappan, Z. Ujang, Polymer-based chelating adsorbents for the selective removal of boron from water and wastewater: a review, React. Funct. Polym. 85 (2014) 54-68.

[35] S. Nishihama, Y. Sumiyoshi, T. Ookubo, K. Yoshizuka, Adsorption of boron using glucamine-based chelate adsorbents, Desalination 310 (2013) 81-86.

[36] S. Samatya, S.A. Tuncel, N. Kabay, Boron removal from RO permeate of geothermal water by monodisperse poly(vinylbenzyl chloride-co-divinylbenzene) beads containing $N$-methyl-D-glucamine, Desalination 364 (2015) 75-81.

[37] Y. Inukai, Y. Tanaka, T. Matsuda, N. Mihara, K. Yamada, N. Nambu, O. Itoh, T. Doi, Y. Kaida, S. Yasuda, Removal of boron(III) by $N$-methylglucamine-type cellulose derivatives with higher adsorption rate, Anal. Chim. Acta 511 (2004) 261-265.

[38] Y.K. Recepoğlu, N. Kabay, İ. Yılmaz-İpek, M. Arda, M. Yüksel, K. Yoshizuka, S. Nishihama, Deboronation of geothermal water using $N$-methyl-D-glucamine based chelating resins and a novel fiber adsorbent: batch and column studies, $\mathrm{J}$. Chem. Technol. Biotechnol. 92 (2017) 1540-1547.

[39] T.M. Ting, M.M. Nasef, K. Hashim, Evaluation of boron adsorption on new radiation grafted fibrous adsorbent containing $N$-methyl-D-glucamine, J. Chem. Technol. Biotechnol. 91 (2016) 2009-2017.

[40] Z. Wang, Z. Wu, Y. Zhang, J. Meng, Hyperbranched-polyol-tethered poly (amic acid) electrospun nanofiber membrane with ultrahigh adsorption capacity for boron removal, Appl. Surf. Sci. 402 (2017) 21-30

[41] P.R. Rout, R.R. Dash, P. Bhunia, Modelling and packed bed column studies on adsorptive removal of phosphate from aqueous solutions by a mixture of ground burnt patties and red soil, Adv. Environ. Res. 3 (3) (2014) 231-251.

[42] G. Yan, T. Viraraghavan, M. Chen, A new model for heavy metal removal in a biosorption column, Adsorpt. Sci. Technol. 19 (1) (2001) 25-43.

[43] I. Yllmaz-İpek, N. Kabay, M. Yüksel, Modeling of fixed bed column studies for removal of boron from geothermal water by selective chelating ion exchange resins, Desalination 310 (2013) 151-157.

[44] E. Bilgin-Simșek, U. Beker, B.F. Senkal, Predicting the dynamics and performance of selective polymeric resins in a fixed bed system for boron removal, Desalination 349 (2014) 39-50.

[45] J. Park, H. Sato, S. Nishihama, K. Yoshizuka, Lithium recovery from geothermal water by combined adsorption methods, Solvent Extr. Ion Exch. 30 (2012) 398-404. 